\title{
Applicability of Geomorphic Index for the Potential Slope Instability in the Three River Region, Eastern Tibetan Plateau
}

\author{
Feng Liu *, Xin Yao and Lingjing Li \\ Institute of Geomechanics, Chinese Academy of Geological Sciences, Beijing 100081, China; \\ Yaox@cags.ac.cn (X.Y.); Lilj@cags.ac.cn (L.L.) \\ * Correspondence: liuf@cags.ac.cn
}

check for updates

Citation: Liu, F.; Yao, X.; Li, L. Applicability of Geomorphic Index for the Potential Slope Instability in the Three River Region, Eastern Tibetan Plateau. Sensors 2021, 21, 6505. https://doi.org/10.3390/s21196505

Academic Editor: Fernando José Aguilar

Received: 2 August 2021

Accepted: 6 September 2021

Published: 29 September 2021

Publisher's Note: MDPI stays neutral with regard to jurisdictional claims in published maps and institutional affiliations.

Copyright: (c) 2021 by the authors. Licensee MDPI, Basel, Switzerland. This article is an open access article distributed under the terms and conditions of the Creative Commons Attribution (CC BY) license (https:// creativecommons.org/licenses/by/ $4.0 /)$.

\begin{abstract}
Geomorphic indices (e.g., the normalized channel steepness index (Ksn) and the stream length-gradient index (SL)) highlight changes in fluvial shapes and gradients. However, the application of these indices was seldom used to identify potential landslide zones. In this study, we used the Ksn and SL indices to detect the significant variations in the stream power along river reaches, which are anomalies associated with landslides, in the Zengqu River watershed, the upper reaches of the Jinsha River. Most of the landslide anomalies originate along the trunk and surrounding tributaries below the knickpoint of the mainstream. This suggests an erosional wave is migrating upstream throughout the drainage area. The fluvial incision may generate over-steepened hillslopes, which could fail in the future. In addition, the divide asymmetry index (DAI) predicts the direction of the divide as the headwaters migrate toward lower relief, higher elevation surfaces. Landslides are expected to occur as the unstable divide migrates. The proposed methodology can benefit the detection and characterization of potential landslide zones. It should improve hazard and risk analysis and the identification of drainage network areas associated with landslides.
\end{abstract}

Keywords: geomorphic indices; potential landslide zone; DEM; Jinsha River

\section{Introduction}

Landslides are highly stochastic geomorphological processes that shape the Earth's landscapes [1,2], causing economic and life losses due to widespread spatial distribution [3]. The landslide hazard mitigation cannot do without the identification of the conditioning factors [4]. The use of optical remote sensing imaging for landslide detection is mainly based on various markers associated with the surface morphological features of the affected area [5-7]. However, it only provides synoptic information about the post-failure deformation surface features and lacks information about the previous deformation state [8]. The InSAR technique complements the abovementioned limitation of the landslide detection based on optical imagery $[9,10]$. Regardless of the type of remote sensing method, understanding the lithology, tectonics, topography, and climate is a fundamental prerequisite for landslide detection. Indeed, the interactions between tectonics, erosion, and climate change are a basic tenet of the tectonic geomorphology [11]. The surface processes associated with landslides can be investigated based on the river incision and drainage basin morphology in highly incised and rugged terrain. However, the method of studying the tectonic geomorphology has seldom been used to identify regions where landslides may occur along the valley sides of stream channels and watershed divide. For example, the anomalous values of the stream length-gradient (SL) index were used to analyze the change in the gradient along a channel affected by landslides [12-15]. However, they did not assess the potential regions that may be prone to landslides. Here, we focused on the Zengqu River, which is a tributary of the upper part of the Jinsha River. The region where landslides may occur was predicted via the geomorphic index method. This study aimed to provide a means of diagnosing potential hillslope failure on the valley side and drainage 
divide. The results of this study provide a possible hillslope deformation target for early landslide identification.

\section{Study Area}

The Three Rivers Region (TRR) is located on the southeastern margin of the Tibetan Plateau (Figure 1a). The morphology of the TRR is characterized by the elongate, roughly parallel drainages of the Nu River, Lancang River, and Jinsha River. The tectonic activity in the TRR has mainly been characterized by strike-slip motion in the north and transtensional stress in the south during the Quaternary [16-18]. The most active, fault in the TRR is the Ganzi Fault system, a left-slip strike-slip system in the northern Jinsha watershed [19]. In addition, the active structures in the TRR also include a series of normal faults in the upper Jinsha River and Nu River watersheds [19]. The rocks are mainly sedimentary in the upper watersheds, and a mixture of sedimentary and deeply exhumed metamorphic rocks are exposed in the lower watersheds in the TRR [20]. The significant geomorphological feature is pervasive low relief, high-elevation topography, which is separated by incised canyons with high reliefs in SE Tibet [21-23]. In the TRR, the low relief, high-elevation surfaces are perched patches in the upper reaches (Figure 1a), while these surfaces have been completely eroded away in the lower watersheds [20].
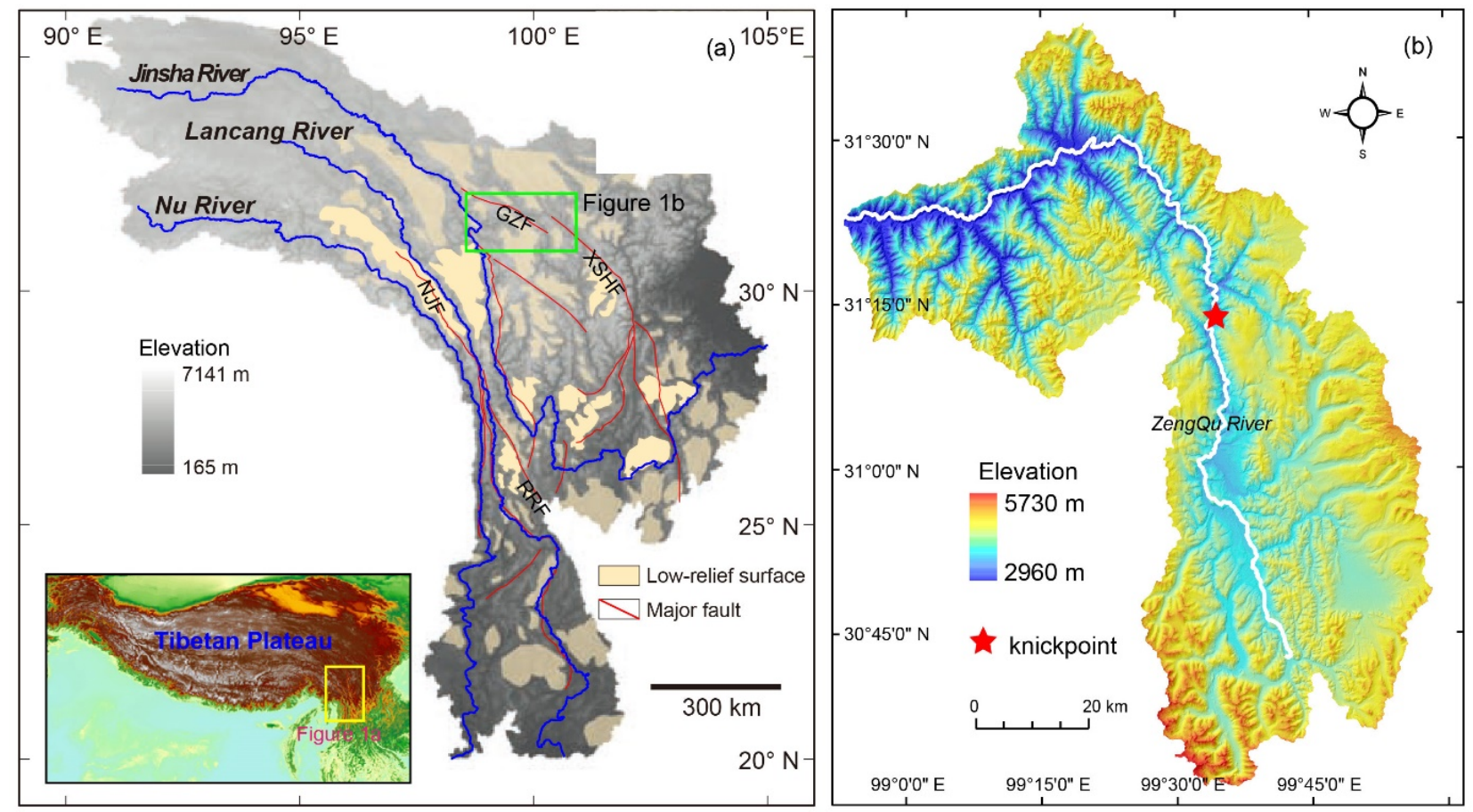

Figure 1. Topographic and fluvial characterization of the Three Rivers Region (TRR) (After Yang et al., 2015) (a) and the Zengqu River watershed (b). Abbreviations for some major faults: GZF: Ganzi fault; NJF: Nu Jiang fault; RRF: Red River fault; XSHF: Xianshuihe fault.

The Zengqu River is a tributary of the upstream part of the Jinsha River (Figure 1b). It flows across different tectono-stratigraphic units and faults (Figure 2a). The lithological boundary and faults do not result in significant slope breaks in the longitudinal profile of the Zengqu River. The longitudinal profile indicates that the Zengqu River is in a transient state with a knickpoint (Figure 2b). Consequently, the channel is a deeply incised valley below the knickpoint. In contrast, the headwater of the Zengqu River has a lower relief. However, the precipitation does not exhibit a significant spatial gradient in the watershed due to the topographic effects (Figure 3 ). 


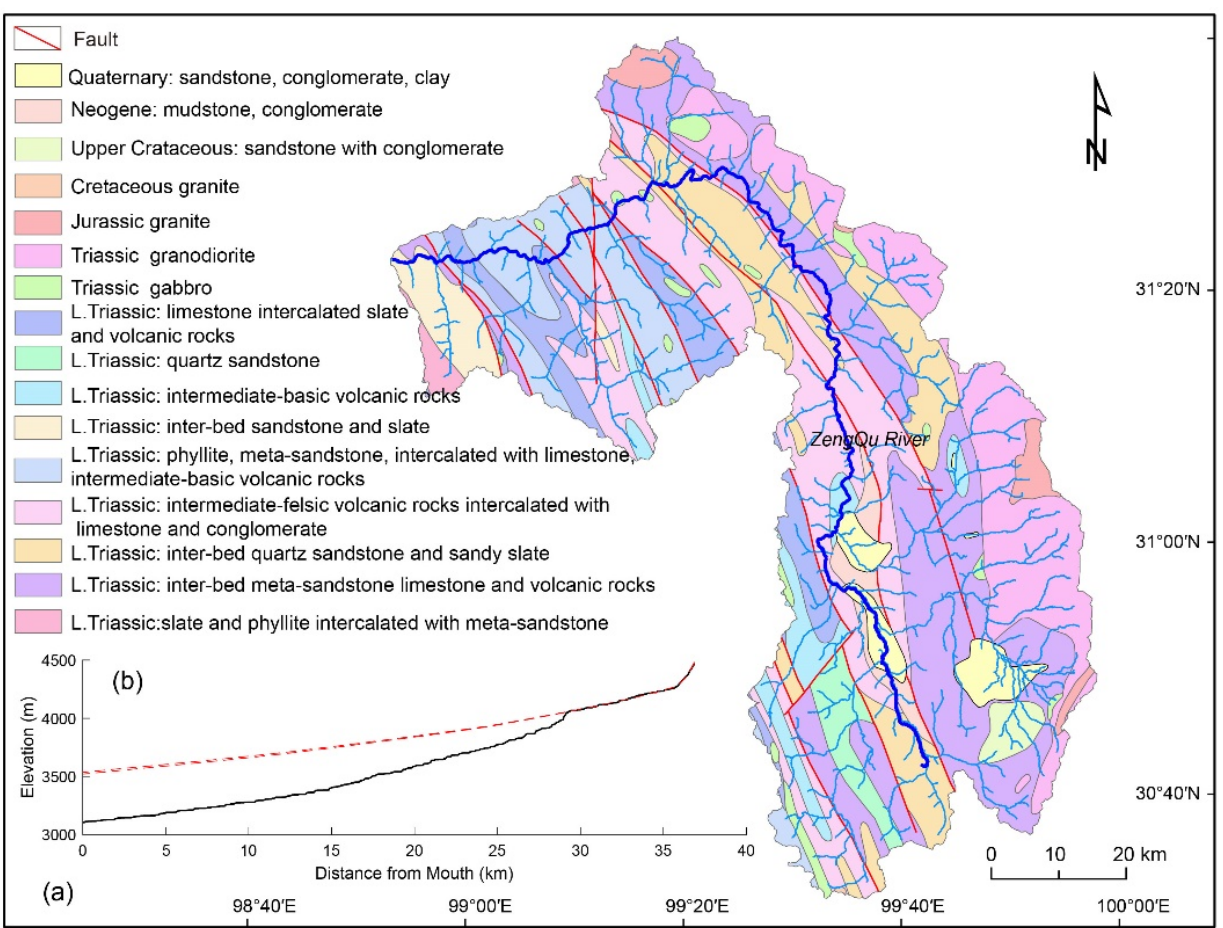

Figure 2. Simplified geological map (after 1:500,000 Chinese geological map) (a,b) reconstructed river long profile of the trunk stream of the Zengqu river extracted from the 30-m-resolution SRTM-DEM (derived from https:/ / earthexplorer.usgs.gov/, accessed on 20 October 2020) (red dotted line is paleo-river profile and black line is modern river profile).

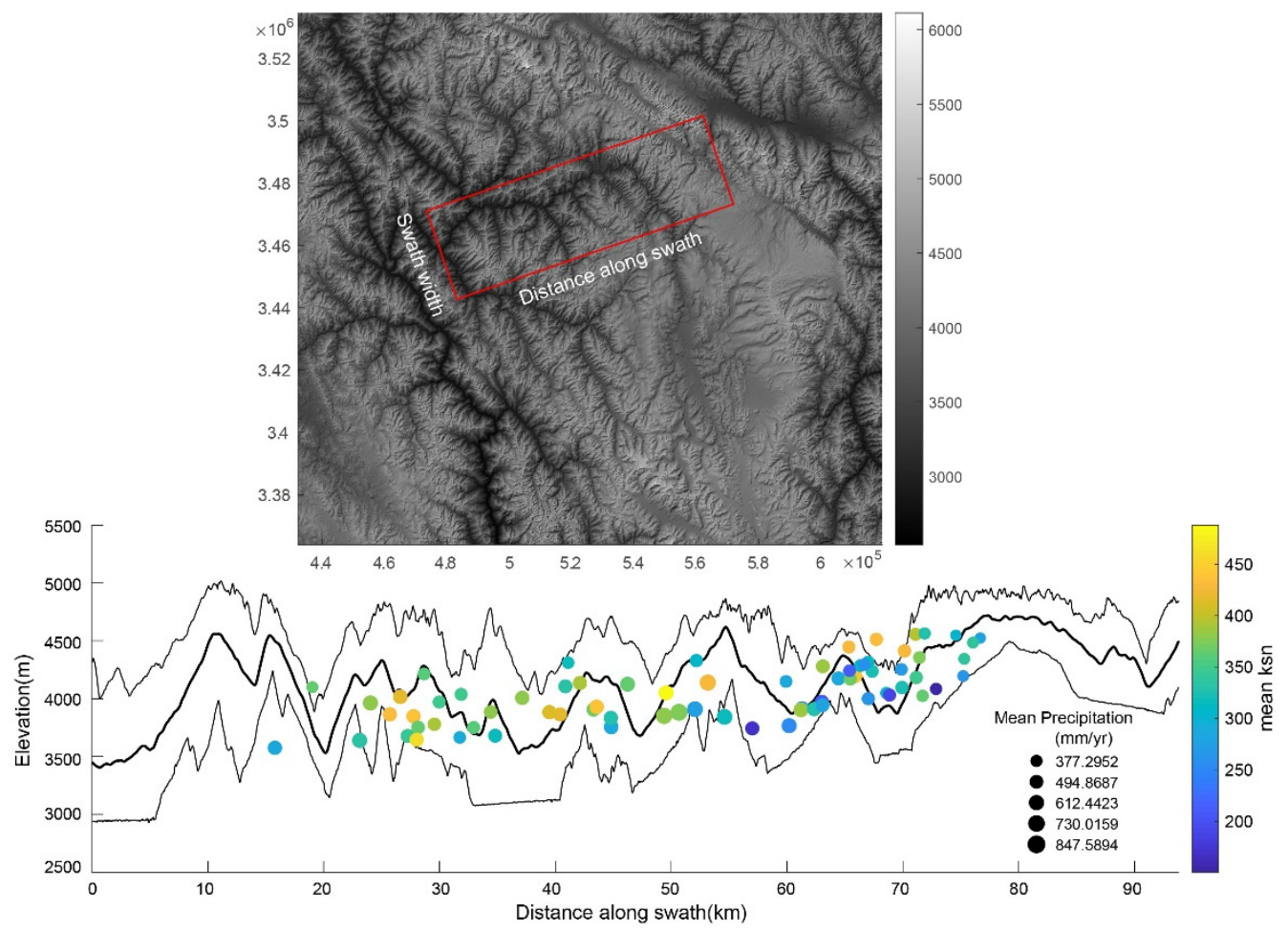

Figure 3. Swath profiles across the Zengqu River. (Upper plot): location of swath topographic profiles. (Lower plot): the black lines are maximum, mean, and minimum elevations along a 10-km wide swath from top to bottom, respectively. Mean annual averaged precipitation within basins

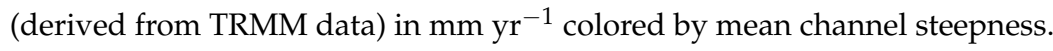




\section{Materials and Methods}

The evolution of the topography is coupled to the changes in the river channel network in the TRR [24]. The normalized channel steepness index (Ksn), which is the slope of the channel normalized by the drainage area $[25,26]$, was used to map the spatial changes in the fluvial incision capacity along the Zengqu River (Figure 4a). Because it is highly sensitive to changes in the channel gradient and can highlight the significant perturbations along a river [13], the SL index was used to detect the features of the surface processes associated with landslides in this study (Figure $4 \mathrm{~b}$ ). We assessed the relationship between the fluvial incision and the abnormal channel gradient based on the transient state of the Zengqu River. In the headwater region, the divide asymmetry index was used to determine whether the divide was stable and to predict the possible direction of the divide (Figure 4c). All indices can be calculated by the digital elevation model (DEM). We used the SRTM DEM (30 m resolution, derived from https: / / earthexplorer.usgs.gov/, accessed on 20 October 2020) to calculate the geomorphic indices. Based on these results, the regions where landslides may occur were identified.

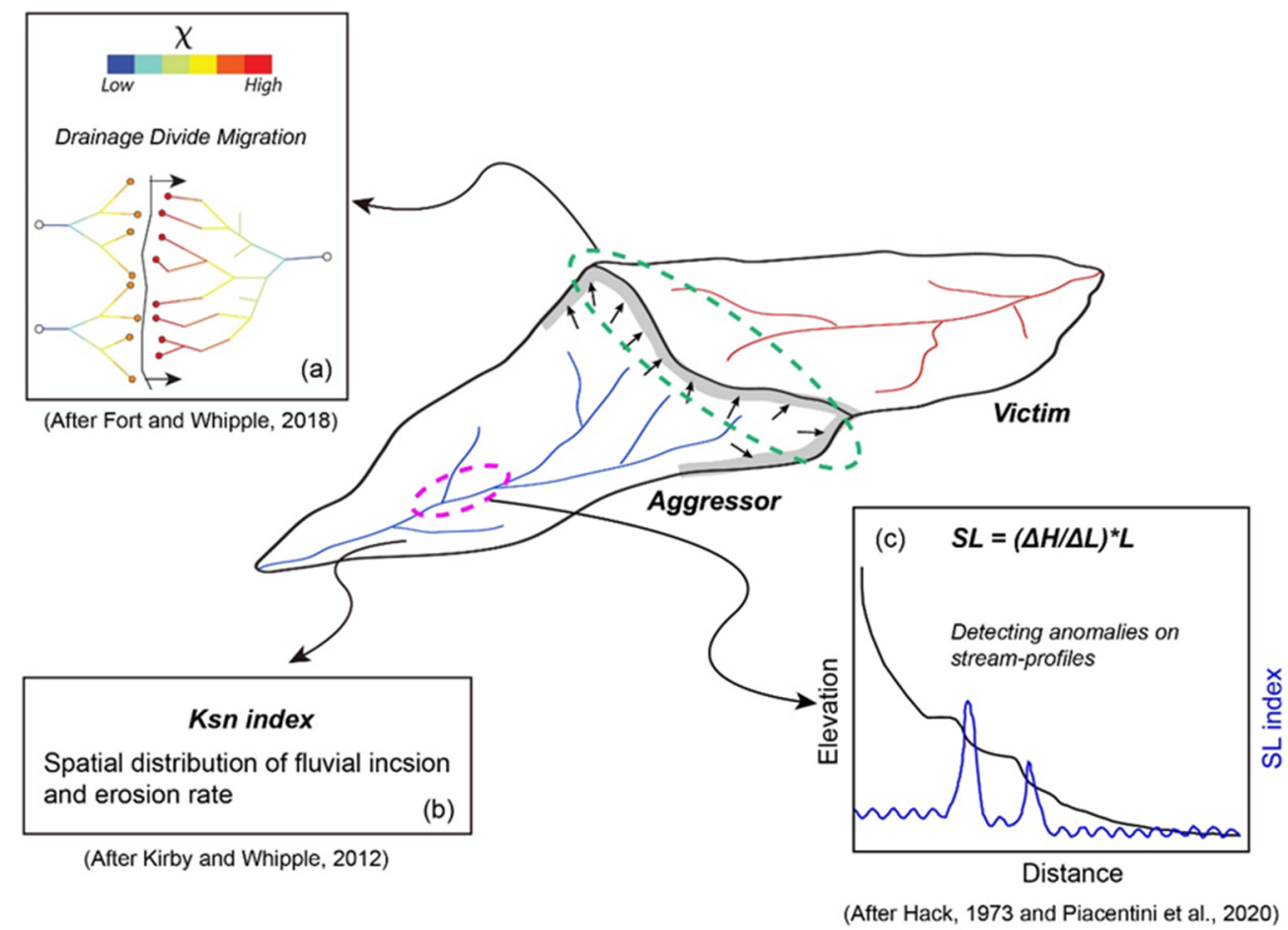

Figure 4. Cartoon plot show the methods adopted in this study on basis of basin scale (after [25]). (a) The parameter $X$ provides a prediction of divide motion; (b) The Ksn index derived from Equation (1) indicate fluvial incision and associated with erosion rates; (c) The SL index (Equation (2)) highlights anomalous changes in river gradients.

\subsection{Channel Steepness Index}

The fluvial profiles and the channel steepness index are valuable tools for evaluating river incision in response to tectonics, climate, and rock properties [27-30]. Under steadystate or dynamic equilibrium conditions, under which uplift and erosion are spatially uniform, bedrock channels exhibit a power law relationship between the channel slope $(S)$ and the drainage area $(A)[31,32]$ :

$$
S=K S A^{-\theta}
$$

where $K s$ is the channel steepness index, and $\theta$ is the channel concavity index.

The above-mentioned power-law function is only valid for drainage areas above a critical threshold [33]. Generally, the minimum drainage area is determined by setting an area of $1 \mathrm{~km}^{2}$ when identifying the channel initiation points that separate the channels from 
the hillslopes [34]. The normalized steepness index (Ksn) allows the comparison of the steepness of channels in different drainage areas [29,34]. In addition, the Ksn values exhibit a meaningful correlation with the catchment-mean erosion rates determined from the concentrations of cosmogenic nuclides in river sediments [29,35,36]. Recently, the Caucasus case study revealed that the relative variations in the erosion rate could be inferred by combining the mean catchment normal channel steepness and the hillslope angle without the mean catchment erosion rate [37].

The uncertainties of the elevation data and the derived slope data may lead to unreliable channel steepness index results using the slope-area method [38]. $X$ was proposed as a proxy map of the dynamic evolution of river networks with steady-state river geometry [38]. Under steady state conditions between uplift and erosion, the relationship between the channel elevation and $\mathrm{X}$ is expected to be linear, with a slope equal to the channel steepness [39]. Landslides can cause drainage divide migration [40], and erosion rates are balanced across divides in tectonically active landscapes [41,42]. However, the interpretation of $\chi$-anomalies across a divide requires some caution due to the assumption of uniform uplift, rock erodibility, and climatic conditions, which may not occur in natural systems [39]. Previous studies have shown that $\chi$-anomalies can occur even when a divide is immobile [27,43]. As an alternative metric of divide stability, Gilbert's metrics, which includes the channel elevation, mean upstream gradient, mean upstream relief, and $X$, was proposed [41]. However, given the manual selection of divides and the across-divide comparisons in these studies, unwanted subjectivity was inevitably introduced [44]. Consequently, the divide asymmetry index (DAI) was proposed for the topographic analysis of divide migration [44]. The DAI is defined as the absolute value of the across-divide difference in the hillslope relief $(\Delta \mathrm{HR})$ normalized by the across-divide sum of the hillslope relief ( $\Sigma$ HR) [44]. The DAI ranges from 0 to 1, i.e., from entirely symmetric to mostly asymmetric, respectively. Thus, we used the DAI to identify the unstable divides in this study. Following the method described by Scherler and Schwanghart (2020), the DAI calculations in this study were conducted in TopoToolbox v2 [45].

\subsection{SL Index}

The SL index is another important geomorphic proxy that quantifies the stream profile's steepness [44]. It is calculated using the following equation at the reach scale:

$$
\mathrm{SL}=(\Delta \mathrm{H} / \Delta \mathrm{L}) * \mathrm{~L},
$$

where $\mathrm{L}$ is the stream length measured from the headwaters to the reach midpoint, and $\Delta \mathrm{H} / \Delta \mathrm{L}$ is the local stream gradient. The SL index is typically used to determine the gradient changes along the stream's longitudinal profile associated with tectonic uplift, rock type, and/or surface processes [46-48]. However, the interpretation of the traditional SL index values is limited by the subjective choice of thresholds for defining the anomalous values along the channel profile $[13,14]$. Recently, hotspot and cluster analysis of the SL index (SL-HCA) was proposed to improve the visualization of the anomalous values in the identification of tectonic structures and large landslides [14]. The SLix toolbox can be used to obtain the SL index map via the SL-HCA method [48]. Indeed, the SL anomaly zones are associated with rapid changes in the channel gradient (e.g., knickpoint) along the longitudinal profile. For bedrock or mixed bedrock-alluvial channels, interactions between the changes in the bedrock lithology, tectonic structures, and mass movements and the streambed are the potential geological and geomorphological triggers of the anomalous SL values [14].

\section{Results}

The SL-HCA anomaly map presents the distribution of the kernel density values of the SL index. Based on the threshold value equal to $1 \sigma$ from the mean kernel density values of the SL index [14], the SL index anomaly map of the Zengqu River was produced (Figure 5). Based on this classification, we identified 30 SL-HCA anomalies in the study 
area. The anomalies were mainly concentrated in the tributary below the knickpoint in the Zengqu River and the two largest anomalies were located along the mainstream in anomaly region 3 (Figure 5). The anomalies were located at the boundaries between the lithological units in regions 1 and 6 (Figure 5).

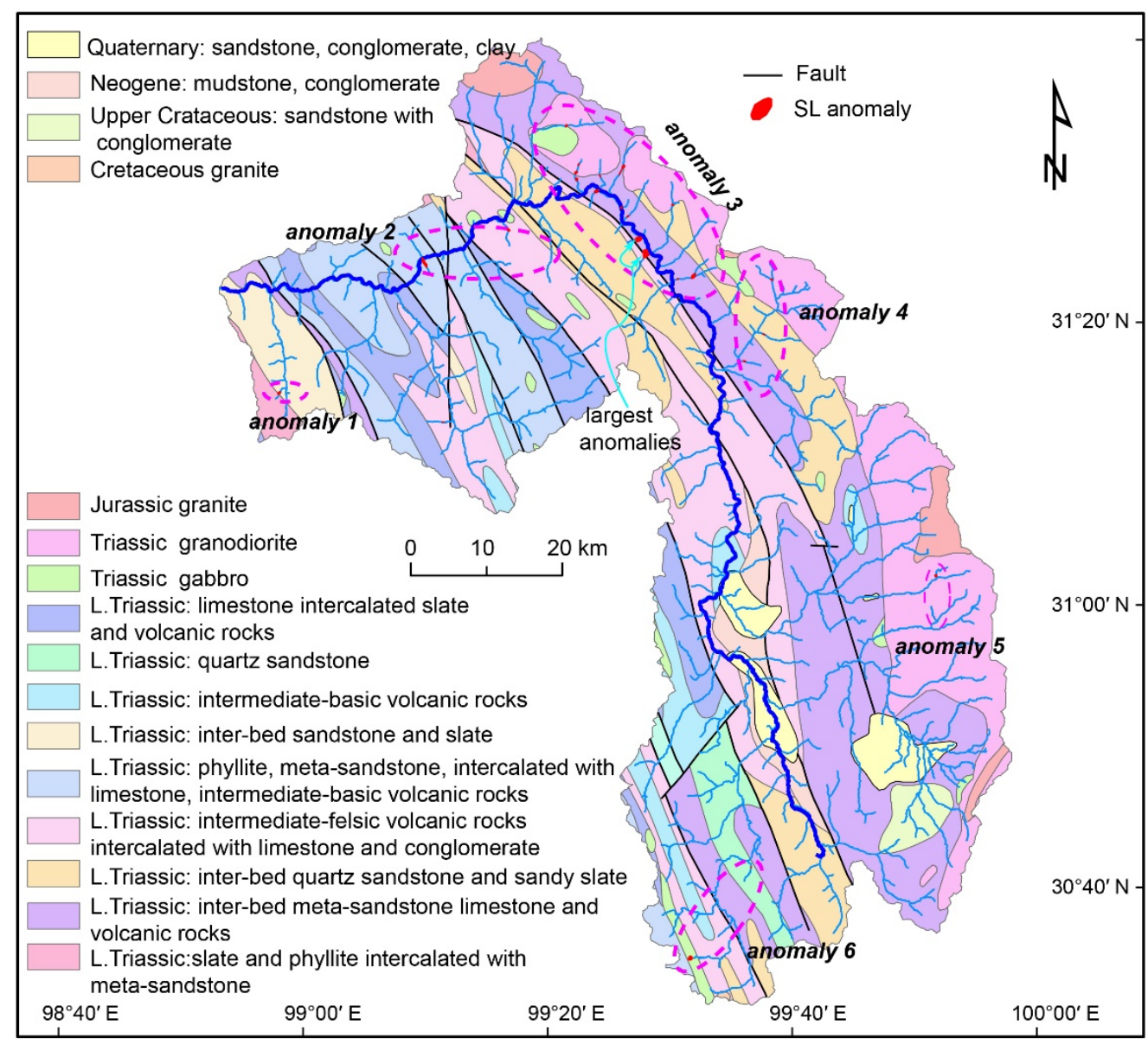

Figure 5. SL index anomalies and the catchment geology. The ellipses with magenta dashed line is significant SL index anomalous.

The regional distribution of the Ksn values was highly variable (Figure 6). The mean Ksn value varied from 20 to $200 \mathrm{~m}^{0.9}$. The high Ksn values were predominantly located in the northern part of the study area along the trunk of the Zengqu River. The strongest incision of the rivers occurs in the lower and middle reaches of the river, which is outlined by the spatial distribution of the Ksn.

Figure 6 shows how the DAI varied with distance along the divide network of the Zengqu River catchment. Some notable deviations occurred at divide distances of $\sim 30-45$, $\sim 140, \sim 200-260$, and $\sim 380-400 \mathrm{~km}$, and were typically associated with asymmetric divides (Figure 7). The most significant deviations from the average values occurred at divide distance of $\sim 0-25 \mathrm{~km}$. These potential migrated divides can be seen in the catchment boundary regions with significant local relief (Figure 8), and many clustered along the eastern and western edges of the catchment. The predicted migration direction is shown in Figure 8 based on the orientations of the divide segments and their mean DAI magnitude. Consequently, most of the divide migration would result in area loss of the Zengqu River catchment from higher to lower relief. 


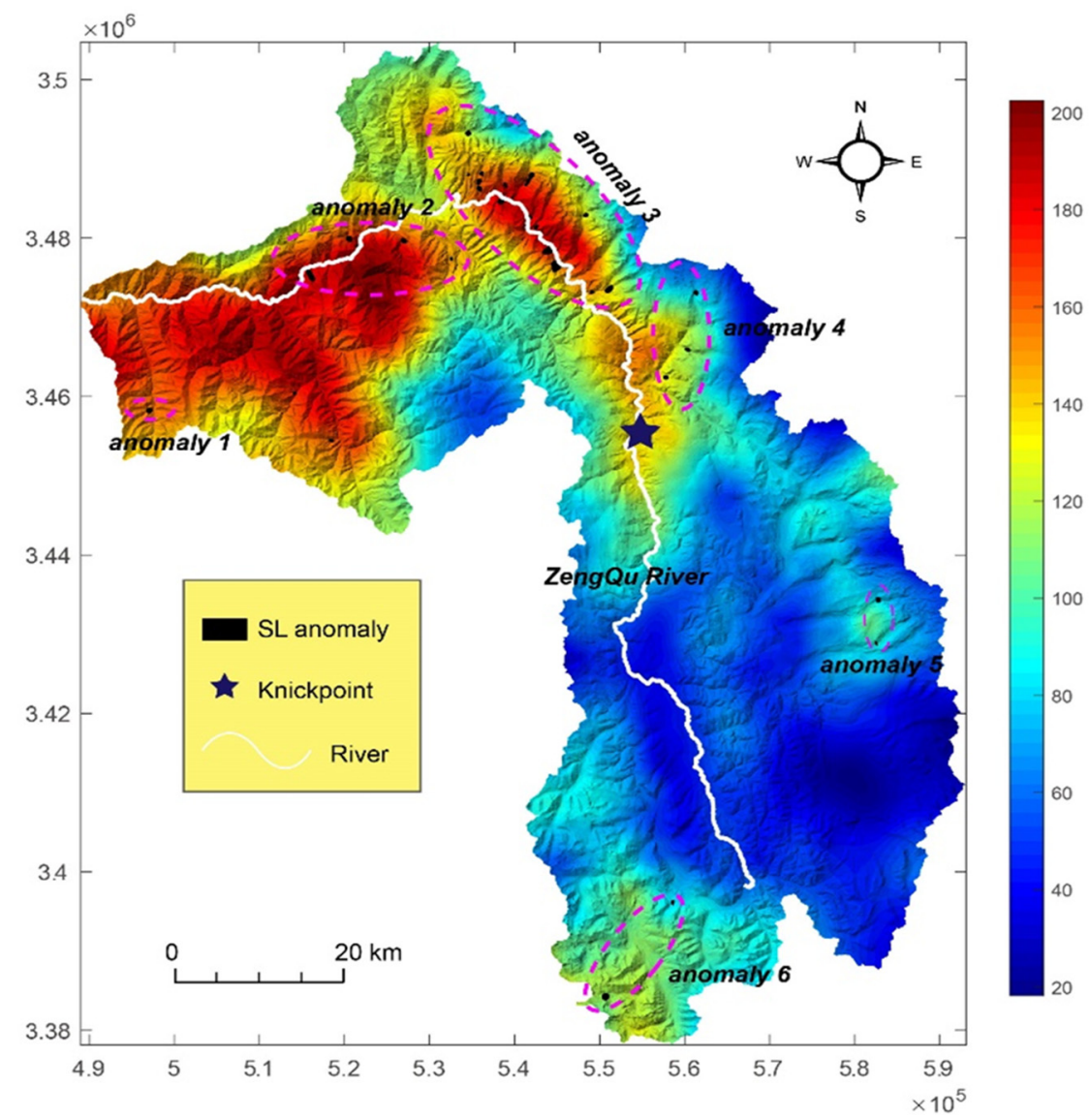

Figure 6. SL index anomalies and the spatial distribution of Ksn. The ellipses with magenta dashed line is significant SL index anomalous.
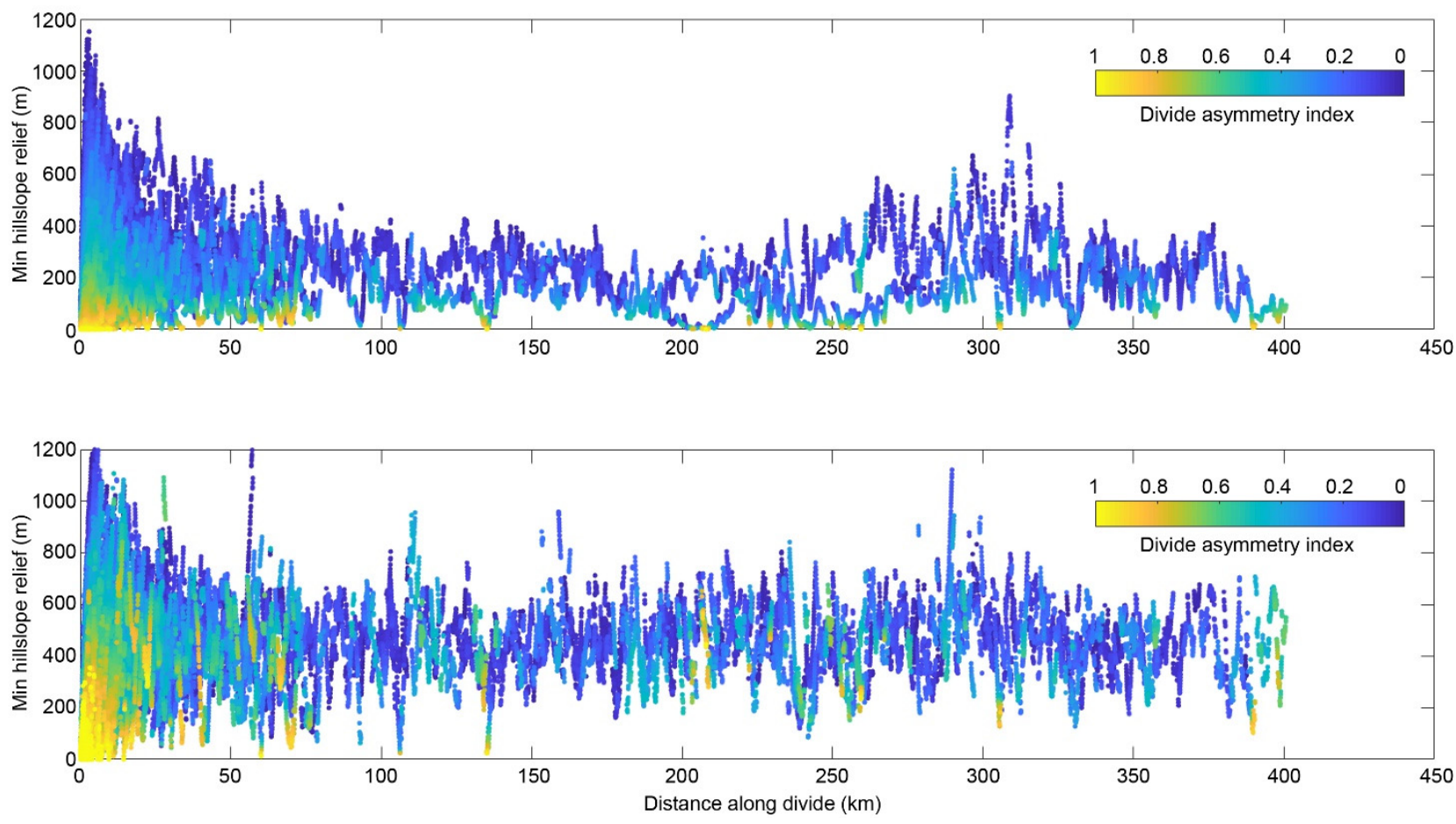

Figure 7. Minimum flow distance along the divide network of the Zengqu River catchment. Colors denote the divide asymmetry index (DAI). 


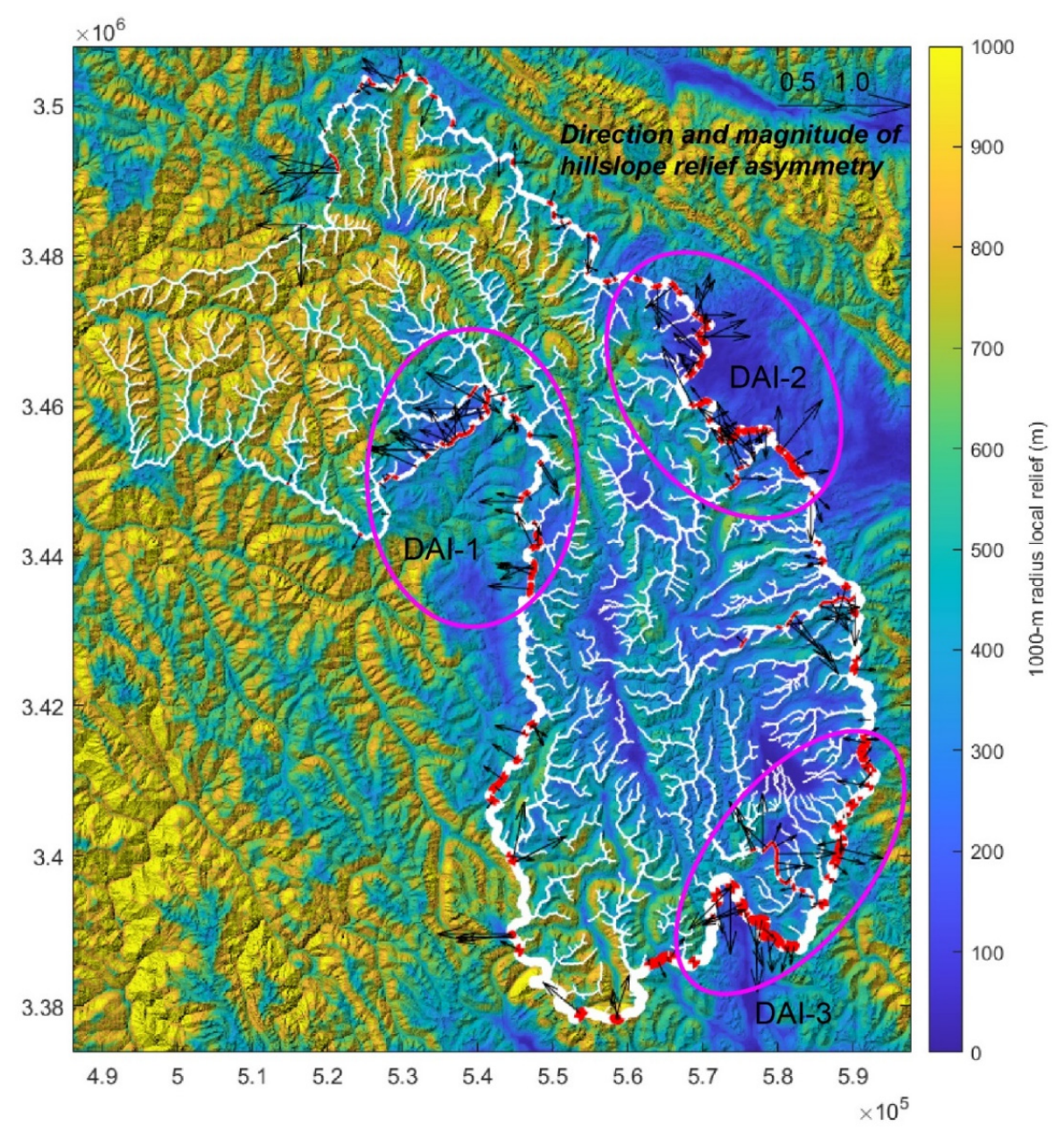

Figure 8. Anomalous divides in the Zengqu River catchment. White lines show the divide network, and red lines depict asymmetric (DAI > 0.4) divide edges. Black arrows indicate the direction and magnitude of the DAI, with the arrow pointing in the direction of the inferred direction of divide migration. The ellipses with the magenta line is significant anomalous divides.

\section{Discussion}

\subsection{SL-HCA Anomalies and Potential Landslide Zones}

Generally, the anomalies detected using the SL-HCA method can be classified as three types related to landslides, lithology, and tectonics [12,47]. Based on the spatial distribution of the 30 anomalies identified in this study, we suggest that most of the anomalies are landslide-type anomalies. The anomalies related to faults are interpreted as having a tectonic origin [49]. The Zengqu River flows across several fault zones (Figure 2a). However, these faults do not result in obvious anomalies along the mainstream of the Zengqu River. This can be validated from the longitudinal profile of the Zengqu River (Figure 2b). In anomaly region 2, the two largest anomalies are distributed along the fault line, not along the mainstream of the Zengqu River (Figure 5). Tectonic anomalies are longer than those related to lithological contacts and landslides [49]. Thus, they probably have a tectonic origin. The anomalies located at the lithological boundaries are classified as having a lithological origin $[13,14]$. In anomaly regions 2 and 6 , few of the anomalies are located at lithological boundaries (Figure 8). The changes in the bedrock's resistance to fluvial erosion cause the morphology anomalies along the channel's gradient. The landslide anomalies are frequently short in length [49]. The shorter the anomaly, the more likely it is to have a landslide origin [14]. Thus, we suggest that the remaining anomalies in the study area may be mainly associated with landslides.

The landslide anomalies may be related to the transient state of the Zengqu River. The longitudinal profile of the Zengqu River indicates that the main trunk is in a transient 
state (Figure $2 b$ ). This suggests that an erosional wave will migrate upstream throughout the drainage system $[34,50]$ before the channel reaches a new steady state. During this process, the river incision will most likely predispose the hillslope to mass movement that could dam the valley and induce channel gradient anomalies. If this case is true, the region between anomaly 3 and the knickpoint is a potential landslide zone (Figure 5). Based on the spatial distribution, the channel exhibits significant incision from the outlet to anomaly region 2 . However, few landslide anomalies were identified in this region. In contrast, a large quantity of landslide anomalies are distributed along the main trunk and the surrounding tributaries in the anomaly region 3 (Figure 5). This also suggests that anomaly region 3 has already transmitted the erosional wave to its tributaries. That is, the reach below anomaly region 3 is in a nearly steady state. The channel gradient anomalies are minimal or have already disappeared, which may not be captured by the SL-HCA method. As the knickpoint of the trunk migrates upstream over time, the base level of the channel and the surrounding tributaries will change in the zone above anomaly region 3. Consequently, the fluvial incision may generate over-steepened hillslopes that could fail in the future.

\subsection{Divide Migration and the Potential Landslide Zones}

The DAI can be used to predict the direction of the divide as the headwaters migrate toward lower relief, higher elevation surfaces (Figure 7). The across-divide difference in the relief is a more direct proxy for erosion, and divides are expected to migrate from high relief to low relief [43]. Figure 7 shows the three main unstable divide regions. We suggest that region DAI-2 is a potential landslide zone. The segment of the divide in region DAI-2 is adjacent to a large patch of low-relief surfaces (Figure 7). In the three rivers region, low-relief surfaces at high elevations are transiently produced as a result of the dynamic reorganization of the river networks [51]. They may survive for some time before being degraded or captured as streams erode inwards from their outer perimeters [52]. These lowrelief surfaces suggest less exhumation due to lower long-term exhumation rates and/or shorter durations of fluvial incision [20]. The erosion rates derived from low-temperature thermochronometry exhibit variable gradients from downstream to upstream in the three rivers region [24]. A similar spatial pattern of erosion was found based on detrital 10Be data [20]. This regional context implies cross-divide contrasts in erosion, and thus an unstable divide may emerge in region DAI-2.

It should be noted that not all of the identified anomalous divides are in fact unstable and migrating with time according to the proxy of the hillslope relief, flow distance, and divide asymmetry [44]. For regions DAI-1 and DAI-3, we are not sure of the cross-divide contrasts in erosion due to the comparatively small area of the low-relief surface compared to that in region DAI-2. Thus, it is not easy to determine whether their divides are unstable. Our approach provides a means of identifying the potential failure of hillslopes due to river incisions on the watershed scale. However, it does not provide a quantitative map of when and where landslides may occur.

\section{Conclusions}

The SL index was used to investigate the abnormal gradient along the Zengqu River. We identified 30 anomalies distributed across the study area. Most of them are landslide anomalies. The landslide anomalies mainly cluster in the high fluvial incision area, below the main knickpoint of the Zengqu River. They occurred in response to the base level perturbation caused by the progression of erosion upstream. The fluvial incision may generate over-steepened hillslopes that could fail in the future as the knickpoint of the trunk migrates upstream over time. The DAI can be used to predict the direction of the divide as the headwaters migrate toward the lower relief, higher elevation surfaces. The across-divide difference in the relief is expected to cause landslides as the erosion migrates from high relief to low relief. The proposed methodology can benefit the detection and characterization of potential landslide zones. 
Author Contributions: Conceptualization, F.L. and X.Y.; writing-original draft preparation, F.L.; writing-review and editing, X.Y. and L.L.; funding acquisition, X.Y. All authors have read and agreed to the published version of the manuscript.

Funding: This work was funded by the National Key Research and Development Program of China (no. 2018YFC1505002), the second Tibetan Plateau Scientific Expedition and Research Program (no. 2019QZKK0901) and the National Science Foundation of China (no. 41672204, 41972210).

Institutional Review Board Statement: Not applicable.

Informed Consent Statement: Not applicable.

Data Availability Statement: Not applicable.

Conflicts of Interest: The authors declare no conflict of interest.

\section{References}

1. Densmore, A.L.; Anderson, R.S.; McAdoo, B.G.; Ellis, M.A. Hillslope Evolution by Bedrock Landslides. Science 1997, $275,369-372$. [CrossRef]

2. Roering, J.J. Landslides limit mountain relief. Nat. Geosci. 2012, 5, 446-447. [CrossRef]

3. Gutiérrez, F.; Soldati, M.; Audemard, F.; Balteanu, D. Recent advances in landslide investigation: Issues and perspec-tives. Geomorphology 2010, 124, 95-101. [CrossRef]

4. Chalkias, C.; Polykretis, C.; Karymbalis, E.; Soldati, M.; Ghinoi, A.; Ferentinou, M. Exploring spatial non-stationarity in the relationships between landslide susceptibility and conditioning factors: A local modeling approach using geographically weighted regression. Bull. Int. Assoc. Eng. Geol. 2020, 79, 2799-2814. [CrossRef]

5. Guzzetti, F.; Carrara, A.; Cardinali, M.; Reichenbach, P. Landslide hazard evaluation: A review of current tech-niques and their application in a multi-scale study, Central Italy. Geomorphology 1999, 31, 181-216. [CrossRef]

6. Van Westen, C.J.; Castellanos, E.; Kuriakose, S.L. Spatial data for landslide susceptibility, hazard, and vulnerability assessment: An overview. Eng. Geol. 2008, 102, 112-131. [CrossRef]

7. Ray, R.L.; Lazzari, M.; Olutimehin, T. Remote sensing approaches and related techniques to map and study land-slides. In Landslides; Ray, R., Lazzari, M., Eds.; Intech Open: Rijeka, Croatia, 2020.

8. Prakash, N.; Manconi, A.; Loew, S. Mapping Landslides on EO Data: Performance of Deep Learning Models vs. Traditional Machine Learning Models. Remote Sens. 2020, 12, 346. [CrossRef]

9. Mondini, A.C.; Guzzetti, F.; Chang, K.-T.; Monserrat, O.; Martha, T.R.; Manconi, A. Landslide failures detection and mapping using Synthetic Aperture Radar: Past, present and future. Earth-Sci. Rev. 2021, 216, 103574. [CrossRef]

10. Solari, L.; Del Soldato, M.; Raspini, F.; Barra, A.; Bianchini, S.; Confuorto, P.; Casagli, N.; Crosetto, M. Review of Satellite Interferometry for Landslide Detection in Italy. Remote Sens. 2020, 12, 1351. [CrossRef]

11. Burbank, D.W.; Anderson, R.S. Tectonic Geomorphology; Blackwell Science: Oxford, UK, 2012.

12. El Hamdouni, R.; Irigaray, C.; Jiménez-Perálvarez, J.D.; Chacón, J. Correlations analysis between landslides and stream lengthgradient (SL) index in the southern slopes of Sierra Nevada (Granada, Spain). In Geologically Active; Williams, A.L., Pinches, G.M., Chin, C.Y., McMorran, T.J., Massey, C.Y., Eds.; Taylor and Francis Group: London, UK, 2010; pp. 141-149.

13. Troiani, F.; Galve, J.P.; Piacentini, D.; Della Seta, M.; Guerrero, J. Spatial analysis of stream length-gradient (SL) index for detecting hillslope processes: A case of the Gállego River headwaters (Central Pyrenees, Spain). Geomorphology 2014, 214, 183-197. [CrossRef]

14. Troiani, F.; Piacentini, D.; Della Seta, M.; Galve, J.P. Stream Length-gradient Hotspot and Cluster Analysis (SL-HCA ) to fine-tune the detection and interpretation of knickzones on longitudinal profiles. Catena 2017, 156, 30-41. [CrossRef]

15. Subiela, G.B.; Guinau, M.; Galve, J.P.; Ortuño, M.; Viaplana-Muzas, M.; Pérez-Peña, J.V. Suitability of geomorphological indices for the automatic identification of landslides affecting the drainage network: Examples from the Pyrenees. In Proceedings of the 20th EGU General Assembly, Vienna, Austria, 4-13 April 2018.

16. Tapponnier, P.; Peltzer, G.; Armijo, R. On the mechanics of the collision between India and Asia. Geol. Soc. Lond. Spéc. Publ. 1986, 19, 113-157. [CrossRef]

17. Tapponnier, P.; Zhiqin, X.; Roger, F.; Meyer, B.; Arnaud, N.; Wittlinger, G.; Jingsui, Y. Oblique Stepwise Rise and Growth of the Tibet Plateau. Science 2001, 294, 1671-1677. [CrossRef]

18. Wang, E.; Burchfiel, B.C.; Royden, L.H.; Chen, L.; Chen, J.; Li, W.; Chen, Z.; Wang, E.; Burchfiel, B.C.; Royden, L.H.; et al. Late Cenozoic Xianshuihe-Xiaojiang, Red River, and Dali Fault Systems of Southwestern Sichuan and Central Yunnan, China; Geological Society of America: Boulder, CO, USA, 1998; pp. 1-108.

19. Taylor, M.; Yin, A. Active structures of the Himalayan-Tibetan orogen and their relationships to earthquake dis-tribution, contemporary strain field, and Cenozoic volcanism. Geosphere 2009, 5, 199-214. [CrossRef]

20. Henck, A.C.; Huntington, K.W.; Stone, J.O.; Montgomery, D.R.; Hallet, B. Spatial controls on erosion in the Three Rivers Region, southeastern Tibet and southwestern China. Earth Planet. Sci. Lett. 2011, 303, 71-83. [CrossRef] 
21. Clark, M.K.; Royden, L.H.; Whipple, K.X.; Burchfiel, B.C.; Zhang, X.; Tang, W. Use of a regional, relict landscape to measure vertical deformation of the eastern Tibetan Plateau. J. Geophys. Res. Space Phys. 2006, 111. [CrossRef]

22. Fox, M.; Carter, A.; Dai, J.-G. How Continuous Are the "Relict" Landscapes of Southeastern Tibet? Front. Earth Sci. 2020, 8. [CrossRef]

23. Liu-Zeng, J.; Tapponnier, P.; Gaudemer, Y.; Ding, L. Quantifying landscape differences across the Tibetan plateau: Implications for topographic relief evolution. J. Geophys. Res. Space Phys. 2008, 113. [CrossRef]

24. Yang, R.; Fellin, M.G.; Herman, F.; Willett, S.D.; Wang, W.; Maden, C. Spatial and temporal pattern of erosion in the Three Rivers Region, southeastern Tibet. Earth Planet. Sci. Lett. 2016, 433, 10-20. [CrossRef]

25. Kirby, E.; Whipple, K. Quantifying differential rock-uplift rates via stream profile analysis. Geology 2001, 29, 415-418. [CrossRef]

26. Ouimet, W.B.; Whipple, K.X.; Granger, D.E. Beyond threshold hillslopes: Channel adjustment to base-level fall in tectonically active mountain ranges. Geology 2009, 37, 579-582. [CrossRef]

27. Whipple, K.X.; Forte, A.M.; DiBiase, R.A.; Gasparini, N.M.; Ouimet, W.B. Timescales of landscape response to divide migration and drainage capture: Implications for the role of divide mobility in landscape evolution. J. Geophys. Res. Earth Surf. 2017, 122, 248-273. [CrossRef]

28. Gallen, S.F. Lithologic controls on landscape dynamics and aquatic species evolution in post-orogenic mountains. Earth Planet. Sci. Lett. 2018, 493, 150-160. [CrossRef]

29. Kirby, E.; Whipple, K.X. Expression of active tectonics in erosional landscapes. J. Struct. Geol. 2012, 44, 54-75. [CrossRef]

30. Murphy, B.P.; Johnson, J.P.L.; Gasparini, N.M.; Sklar, L.S. Chemical weathering as a mechanism for the climatic control of bedrock river incision. Nat. Cell Biol. 2016, 532, 223-227. [CrossRef] [PubMed]

31. Flint, J.J. Stream gradient as a function of order, magnitude, and discharge. Water Resour. Res. 1974, 10, 969-973. [CrossRef]

32. Howard, A.; Kerby, G. Channel changes in badlands. GSA Bull. 1983, 94, 739-752. [CrossRef]

33. Montgomery, D.R.; Foufoula-Georgiou, E. Channel network source representation using digital elevation models. Water Resour. Res. 1993, 29, 3925-3934. [CrossRef]

34. Wobus, C.; Whipple, K.X.; Kirby, E.; Snyder, N.; Johnson, J.; Spyropolou, K.; Crosby, B.; Sheehan, D. Tectonics from topography: Procedures, promise, and pitfalls. In Special Paper 398: Tectonics, Climate, and Landscape Evolution; Geological Society of America: Boulder, CO, USA, 2006; pp. 55-74.

35. DiBiase, R.; Whipple, K.X.; Heimsath, A.M.; Ouimet, W.B. Landscape form and millennial erosion rates in the San Gabriel Mountains, CA. Earth Planet. Sci. Lett. 2010, 289, 134-144. [CrossRef]

36. Safran, E.B.; Bierman, P.R.; Aalto, R.; Dunne, T.; Whipple, K.X.; Caffee, M. Erosion rates driven by channel network incision in the Bolivian Andes. Earth Surf. Process. Landf. 2005, 30, 1007-1024. [CrossRef]

37. Forte, A.M.; Whipple, K.X.; Bookhagen, B.; Rossi, M.W. Decoupling of modern shortening rates, climate, and to-pography in the Caucasus. Earth Planet. Sci. Lett. 2016, 449, 282-294. [CrossRef]

38. Perron, J.T.; Royden, L.H. An integral approach to bedrock river profile analysis. Earth Surf. Process. Landf. 2013, 38, 570-576. [CrossRef]

39. Willett, S.D.; McCoy, S.W.; Perron, J.T.; Goren, L.; Chen, C.-Y. Dynamic Reorganization of River Basins. Science 2014, $343,1248765$. [CrossRef]

40. Dahlquist, M.; West, A.J.; Li, G. Landslide-driven drainage divide migration. Geology 2018, 46, 403-406. [CrossRef]

41. Whipple, K.X. The influence of climate on the tectonic evolution of mountain belts. Nat. Geosci. 2009, 2, 97-104. [CrossRef]

42. Whipple, K.X.; Tucker, G. Dynamics of the stream-power river incision model: Implications for height limits of mountain ranges, landscape response timescales, and research needs. J. Geophys. Res. Space Phys. 1999, 104, 17661-17674. [CrossRef]

43. Forte, A.M.; Whipple, K.X. Criteria and tools for determining drainage divide stability. Earth Planet. Sci. Lett. 2018, 493, 102-117. [CrossRef]

44. Scherler, D.; Schwanghart, W. Drainage divide networks-Part 1: Identification and ordering in digital elevation models. Earth Surf. Dyn. 2020, 8, 245-259. [CrossRef]

45. Schwanghart, W.; Scherler, D. Short Communication: TopoToolbox 2-MATLAB-based software for topographic analysis and modeling in Earth surface sciences. Earth Surf. Dyn. 2014, 2, 1-7. [CrossRef]

46. Hack, J.T. Stream-profile analysis and stream-gradient index. J. Res. US Geol. Surv. 1973, 1, 421-429.

47. Keller, E.A.; Pinter, N. Active Tectonics: Earthquakes, Uplift, and Landscape; Prentice Hall: Upper Saddle River, NJ, USA, 2002.

48. Piacentini, D.; Troiani, F.; Servizi, T.; Nesci, O.; Veneri, F. SLiX: A GIS Toolbox to Support Along-Stream Knickzones Detection through the Computation and Mapping of the Stream Length-Gradient (SL) Index. ISPRS Int. J. Geo-Inf. 2020, 9, 69. [CrossRef]

49. Bermúdez, M.A.; Velandia, F.; García-Delgado, H.; Jiménez, D.; Bernet, M. Exhumation of the southern transpres-sive Bucaramanga fault, eastern Cordillera of Colombia: Insights from detrital, quantitative thermochronology and geo-morphology. J. S. Am. Earth Sci. 2021, 106, 103057. [CrossRef]

50. Whipple, K.; DiBiase, R.; Crosby, B. 9.28 Bedrock Rivers. In Treatise on Geomorphology; Shroder, J.F., Ed.; Academic Press: San Diego, CA, USA, 2013; pp. 550-573.

51. Yang, R.; Willett, S.D.; Goren, L. In situ low-relief landscape formation as a result of river network disruption. Nat. Cell Biol. 2015, 520, 526-529. [CrossRef] [PubMed]

52. Lavé, J. Landscape inversion by stream piracy. Nat. Cell Biol. 2015, 520, 442-443. [CrossRef] [PubMed] 